\title{
UTILIZATION OF SOIL FUNCTION INFORMATION FOR ASSESSING SOIL QUALITY OF RICE FIELD IN THE QUATERNARY-TERTIARY VOLCANIC TRANSITIONAL ZONES IN CENTRAL JAVA
}

\author{
Ajun Prayitno ${ }^{1,2 *}$, Junun Sartohadi², and Makruf Nurudin ${ }^{2}$ \\ ${ }^{1}$ Indonesian Agency of Agricultural Research and Development \\ ${ }^{2}$ Department of Soil Science, Faculty of Agriculture, Universitas Gadjah Mada \\ Submitted: 2019-11-06 Accepted: 2019-12-11
}

\begin{abstract}
Soil quality information of the rice field in the Quaternary-Tertiary volcanic transitional zone has not been specifically reported. Research on the assessment of soil quality widely reported only focuses on the discussion of quantitative-qualitative techniques and the use of minimum data sets without paying serious attention to the soil functions. This study aimed to assess soil quality through qualitative and quantitative methods based on the soil function information approach. The study was conducted in the quaternary-tertiary volcanic transitional zone with special cases of thick soil, high clay content, low nutrient content, high erosion, and vulnerability to landslide, which affects soil quality and farmer cultivation practice. The qualitative soil quality approach was based on the local knowledge of the farmers. The quantitative soil quality indexing was performed with the Soil Management Assessment Framework (SMAF) method to obtain sensitive indicators. The results found that the characteristics of paddy soil had high clay content and thick topsoil layers. The paddy soil is commonly called as ngrawa/mbel soil. The minimum qualitative data sets included color, plant condition, texture, ease of tillage, and drainage. Meanwhile, the minimum quantitative data sets included $\mathrm{Na-dd,} \mathrm{Mg-dd,} \mathrm{texture,}$ bulk density, porosity, and permeability. Information on soil functions obtained included the availability of nutrients, rooting media, root penetration, water storage capacity, and soil permeability. The soil function information approach can be used to assess soil quality in the quaternary-tertiary volcanic transitional zone.
\end{abstract}

Keywords: Rice field, Soil function, Soil quality, Volcanic transitional zone

How to Cite: Prayitno, A., Sartohadi, J., and Nurudin, M. 2019. Utilization of Soil Function Information for Assessing Soil Quality of Rice Field in the Quaternary-Tertiary Volcanic Transitional Zones in Central Java. Sains Tanah Journal of Soil Science and Agroclimatology, 16(2): 169-180 (doi: 10.20961/stjssa.v16i2.35492)

Permalink/DOI: http://dx.doi.org/10.20961/stjssa.v16i2.35492

\section{INTRODUCTION}

Soil quality focuses on the capacity of the soil to meet the needs of human life because it is related to crop productivity. Soil quality is closely related to the environment because the soil is not only a transformation of minerals

* Corresponding Author :

Email:ajun.pray@yahoo.com and organic matter but also a place to grow plants that affect the life on it. Biswas et al. (2017) explained that the assessment of soil quality by identifying key limiting indicators is important so that the function and balance of the soil and crop productivity are maintained. High soil quality values indicate a high level of soil fertility (Arifin, 2011). Information about 
soil quality is very important to evaluate soil productivity and identify suitable land management. Researchers have previously developed quantitative methods for assessing soil quality based on the physical, chemical, and biological properties of the soil (Karlen et al., 2003; Andrews et al., 2004; Obade \& Lal, 2016). Rashidi et al. (2010) added that there are two important factors in the concept of soil quality. The first one that soil has inherent and dynamic properties and the second one is that the assessment of soil quality must reflect soil properties as well as the physical, chemical, and biological processes and interactions.

Soil quality assessment is carried out using a framework prioritizing management objectives, identifying soil functions, and selecting indicators that provide important information related to soil functions. The method of indexing soil quality commonly used is to synthesize soil indicators into a simpler format based on the soil function and its weighting, thus supporting multi-objective decision making (Askari \& Holden, 2015). There are various choices of indicators and methods for integrating scoring of soil quality assessments so that each method has been developed for a specific purpose (Andrews et al., 2004; Lima et al., 2013; Masto et al., 2015; Noviyanto et al., 2017). Bunemann et al. (2018) added that in anthropogenic land, the sensitive soil attributes with intensive land management, such as paddy soil, are necessary. Inundation and puddling of paddy soil cause changes in the physical, chemical, and morphological characteristics of the soil.

Evaluation of soil quality is needed to be continuously developed in agriculture, especially in soil science. Results of qualitative soil quality evaluations have not been widely reported because they are considered not objective. Evaluation of soil quality is not limited to scientific steps, but it also requires an approach that is easily understood by farmers.
Fierer et al. (2007) state that qualitative soil quality information can be assessed by (i) visual inspection (soil color) and depth of plant roots, (ii) soil compactness, (iii) soil fertility, and (iv) crop yields. Soil color is used by farmers to measure organic matter (Adeyolanu \& Ogunkunle, 2016). Morphological visualization methods are used to assess plant growth (Murage et al., 2000). Farmers have practical knowledge from daily experience in the field. Farmers can adjust their farm management by evaluating the soil properties and characteristics of their farmland.

Local information related to land conditions and agricultural management is needed to evaluate soil quality. An ethnopedological approach through semistructured interviews is used to interpret the results of the soil quality qualitatively to make it more accurate according to the site conditions. Ethnopedological approach is used to explain the understanding of farmers (local knowledge) related to the perception of the properties and characteristics of the soil. Farmers' perceptions are integrated by researchers (scientific knowledge) to formulate qualitative soil quality values. According to Obade (2019), an ethnopedological approach using illustrative interviews was carried out to integrate land management information by farmers with the dynamics of soil quality in monitoring agricultural productivity. Farmers' viewpoints are based on soil management experience, rice productivity, and land use, therefore gender, age, education, knowledge, occupation, length of stay, and period of farming can influence the subjectivity of the farmers.

The volcanic transition zone is a transitional zone between quarternary and tertiary age material. Soil formed in volcanic transition zones has unique properties with different developments. Parent material, relief, climate, and geomorphological 
processes occur intensively. Specific characteristics of areas with volcanic transition landscapes are thick soils, high levels of cliffs, low nutrient content, high erosion, and vulnerability to a landslide (Pulungan \& Sartohadi, 2018a). Intensive material transportation occurs in volcanic transitional zones so that colluvial material is found in the depositional zone. Depositional zones tend to have flat reliefs so that farmers use them for agricultural cultivation activities. The adaptation of soil management is carried out by farmers to maximize agricultural cultivation activities in volcanic transition zones. From the farmers' perspective, there are typical local soils in quarternary-tertiary-age volcanic transition zones, namely 'cabuk hitam', 'cabuk putih', 'cabuk grogol', 'lendut', 'lincat', 'lempung', 'baturan', and 'gresik'. Paddy soil is included in a typical local soil, which is called 'lendut', 'ngrawa', or 'mbel'. 'Ngrawa' or 'mbel' soils have thick topsoil, high clay content, and high soil plasticity index. High clay content and high soil plasticity index cause more micropore space than macropore space. Poor soil aeration conditions cause low microorganism activity in the soil.

Although there are a lot of methods and indicators to characterize soil quality, almost no standard soil quality method is used universally. An accurate evaluation of soil quality can be found on a detailed and local scale, however, it has limited site specifications. Based on the characteristic of paddy soil at the study site, soil function indicator was added to determine soil quality index. This study aimed to assess soil quality through qualitative and quantitative methods based on the soil function information approach. The novelty of this research is to add soil function indicators to the weighting factor system and formula soil quality.

\section{MATERIALS AND METHODS Study Area}

The research location is in Bompon subwatershed upstream, Magelang, Central Java (7³2'36.57"-7 $37^{\circ}$ '01.86"S and $110^{\circ} 03^{\prime} 44.43^{\prime \prime}-$ $110^{\circ} 03^{\prime} 55.13^{\prime \prime} \mathrm{E}$ at an elevation of $450 \mathrm{~m}$ asl) with the land use of rainfed rice field. The climate at the study site tends to be rather wet, with an average rainfall of $2,806 \mathrm{~mm} \mathrm{yr}^{-1}$. The bedrock in Bompon sub-watershed upstream is formed from volcanic parent materials in the form of sandy tuffs and andesite breccias. The soil unit from volcanic parent material, with a slightly wet climate. The texture was dominated by clay, has thick soil solum. Land management is classified as heavy due to the depth of more than 1 meter. Soil that is not easy to plow causes poor soil drainage, making the paddy soil easily flooded. The research location is presented in Figure 1.

\section{Soil Sampling and laboratory analysis}

Sampling was done by purposive sampling at a depth of $0-20 \mathrm{~cm}$ and $20-40 \mathrm{~cm}$ with a distance between sample points of $40 \mathrm{~m}$. Soil samples were taken from a composite sample of two replications, consisting of 12 qualitative sample points ( 12 soil samples) and 10 quantitative sample points (20 soil samples). According to Jobbagy \& Jackson (2004), soil quality varies greatly with soil depth, nutrient cycle dynamics, and leaching factors. Visual observation of rice morphology and farmers' interviews were conducted in a semistructured manner. The practical knowledge and experience of farmers in the field were measured to formulate qualitative soil quality. Soil physicochemical parameters are used to formulate quantitative soil quality. Biological parameters are not used because of low microorganism activity. Characteristics of thick soils, high clay content and high plasticity index caused poor soil aeration conditions and disturbed organisms in the soil. Soil quality 
assessment based on soil physico-chemical parameters was also carried out by Govaerts et al. (2006), Rezaei et al. (2006), and Li et al. (2013). Analysis of soil parameters was performed using the instructions of Carter \& Gregorich (2009), including moisture content with gravimetric method, bulk density with ring method, porosity by calculating bulk density and particle density, hydraulic conductivity with permeameter method, texture with hydrometer method, $\mathrm{pH} \mathrm{H}_{2} \mathrm{O}$ with soil: water suspension (1:2.5), organic soil carbon with Walkley and black method, total $\mathrm{N}$ with Kjeldahl method, available $\mathrm{P}$ with Bray method (acid soil) and Olsen method (alkaline soil), and exchangeable $\mathrm{Ca}, \mathrm{Mg}, \mathrm{Na}, \mathrm{K}$ and cation exchange capacity with $1 \mathrm{~N}$ ammonium acetate and $10 \%$ sodium chloride extraction.

\section{Soil Quality}

\section{Qualitative method}

The approach used to formulate a qualitative soil quality index was an illustrative case study. According to Hollweck (2016), illustrative case studies allow the understanding at the local and detailed level for farmers. Individual interview methods with a semi-structured questionnaire were used to collect data in the form of information on conditions and management of the soil as well as on rice production. The weighting process was used based on soil functions and minimum qualitative data sets, including soil color, plant conditions, texture (sand content), ease of tillage, wet-dry periods, and drainage. A qualitative soil quality indexing system is presented in Equation [I] (Adeyolanu \& Ogunkunle, 2016) with modification:

$S Q-Q L=\left(\sum_{i=1}^{n} W i \times S i\right) \times W(S F)$

Where SQ-QL: qualitative soil quality; Wi: variable weight i; Si: variable score i; W(SF): soil function weight.

\section{Quantitative method}

The SMAF method has been developed to assess soil quality with three basic steps, namely: the selection of indicators, interpretation of indicators, and integration into soil quality index values. Andrews et al. (2004) explained that the selection of indicators must be following the objectives of land management, soil function, and sitespecific factors (area or plant sensitivity). Indicator interpretation involves the transformation of each minimum data set using a non-linear scoring curve (Andrews et al., 2002). The assessment uses an algorithm that links the empirical value of the indicator measured by the performance of the soil function. Each indicator size is transformed through an assessment algorithm into a score without units (0 to 1 ), which represents the level of soil function in the system. Equation [2] has been developed by Masto et al. (2007) and Mukhopadhyay et al. (2016) to formulate nonlinear scoring.

$\mathrm{Si}=\mathrm{a} /\left[1+\left(\frac{\mathrm{x}}{\mathrm{x} 0}\right)^{\mathrm{b}}\right]$

Where a: maximum score (1.00); $\mathrm{x}$ : soil properties values; $x 0$ : average value of each soil property; $b$ : gradient value of the equation (-2.5 for 'more is better', 2.5 for 'less is better').

The weighting in the quantitative soil quality index was determined based on varian percentage. The variance percentage was generated from selected Principal Component (PC). The formulation of a quantitative soil quality index is presented in Equation [3]:

SQ-QN $=\left(\sum_{i=1}^{n} \mathrm{Wi} \times \mathrm{Si}\right) \times W(S F)$

Where SQ-QN: quantitative soil quality; Wi: variable weight $i$; $\mathrm{Si}$ : variable score $\mathrm{i}$, $\mathrm{W}(\mathrm{SF})$ : soil function weight

The result at minimum data set was grouped into five soil functions in the agricultural perspective, i.e.: (1) availability of nutrients; (2) rooting media; (3) root 
penetration; (4) water storage capacity; and (5) soil permeability.

\section{Statistical analysis}

Principal Component Analysis (PCA) is performed to determine the minimum data set of sensitive soil properties. The PC value is determined based on eigenvalue $>1$. Correlation analysis is performed to determine the minimum data set on the selected PC. Statistical Analysis Data were analyzed using Minitab software version 16.0 and maps using ArcGIS 10.5 software.

\section{RESULTS}

The study area is located in the disposition zone with colluvium sediment type material. Colluvium deposits allow a mixture of sand and fresh rock fractions to be found. Based on local information, the disposition zone was formed due to a landslide process on the surrounding cliffs. Budianto (2016) added the study area was formed by colluvial plain with material derived from Sumbing Muda volcanic ash mixed with landslide sediment. A total of 12 qualitative sample points were observed according to the minimum data set that had been formulated. Based on Table 1, the condition of plants at the study site was moderate, and the color of the soil showed a red-yellow matrix with a different hue and chroma value.

Texture at the study site was dominated by clay with a consortium of dust fractions and sand minorities. The sand fraction was found at site 1 due to the parent material in the form of sandstone interbreeding. Soil tillage was categorized as moderate to severe caused deep solum and high clay content. The wet-dry periods and drainage have affected from characteristics of soils and climate at the study site.

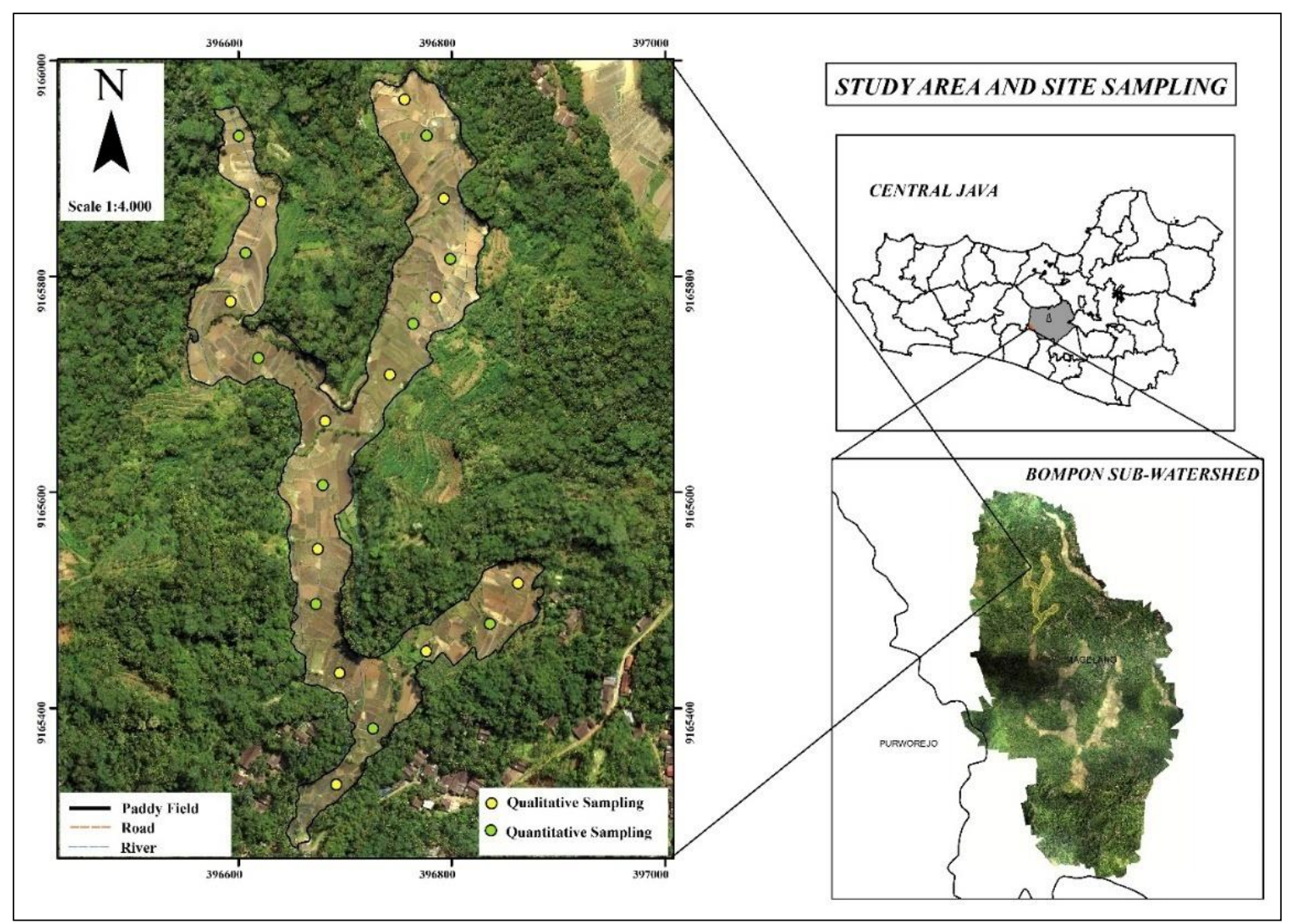

Figure 1. Research location 
Table 1. Qualitative observations in the research location

\begin{tabular}{|c|c|c|c|c|c|c|c|c|c|c|c|c|}
\hline Parameters & Site 1 & Site 2 & Site 3 & Site 4 & Site 5 & Site 6 & Site 7 & Site 8 & Site 9 & Site 10 & Site 11 & Site 12 \\
\hline Soil Color & 5YR 5/4 & 5YR 4/6 & 7.5YR 4/4 & 7.5YR 4/4 & 5YR 5/4 & 10YR 4/6 & 7.5YR 4/4 & 7.5YR 4/6 & 5YR 4/6 & 5YR 4/6 & 5YR 4/6 & 5YR 4/6 \\
\hline Plant condition & Medium & Medium & Medium & Medium & Medium & Medium & Medium & Medium & Medium & Medium & Medium & Medium \\
\hline Field texture & Sandy Clay & Clay & Silty Clay & Clay & Clay & Silty Clay & Silty Clay & Silty Clay & Silty Clay & Silty Clay & Silty Clay & Silty Clay \\
\hline Ease of tillage & Medium & Hard & Hard & Hard & Medium & Medium & Hard & Hard & Medium & Medium & Medium & Medium \\
\hline Dry/wet period & Low & Medium & Medium & Medium & Low & Medium & Medium & Medium & Medium & Medium & Low & Medium \\
\hline Drainage & Low & Medium & Low & Medium & Medium & Medium & Low & Low & Low & Medium & Low & Medium \\
\hline
\end{tabular}

Remarks: 5YR 5/4 (reddish brown); 5YR 4/6 (yellowish red); 7.5YR 4/4 (dark brown); 10YR 4/6 (dark yellowish brown); 7.5YR 4/6 (strong brown); 5YR 4/6 (yellowish red)

Table 2. Physical-chemical properties of the soil

\begin{tabular}{|c|c|c|c|c|c|c|c|c|c|c|c|c|c|c|c|c|c|c|c|c|c|}
\hline \multirow{2}{*}{ Parameters } & \multirow[b]{2}{*}{$(\mathrm{cm})$} & \multicolumn{2}{|c|}{ Site 1} & \multicolumn{2}{|c|}{ Site 2} & \multicolumn{2}{|c|}{ Site 3} & \multicolumn{2}{|c|}{ Site 4} & \multicolumn{2}{|c|}{ Site 5} & \multicolumn{2}{|c|}{ Site 6} & \multicolumn{2}{|c|}{ Site 7} & \multicolumn{2}{|c|}{ Site 8} & \multicolumn{2}{|c|}{ Site 9} & \multicolumn{2}{|c|}{ Site 10} \\
\hline & & $0-20$ & $20-40$ & $0-20$ & $20-40$ & $0-20$ & $20-40$ & $0-20$ & $20-40$ & $0-20$ & $20-40$ & $0-20$ & $20-40$ & $0-20$ & $20-40$ & $0-20$ & $20-40$ & $0-20$ & $20-40$ & $0-20$ & $20-40$ \\
\hline $\mathrm{BD}$ & & 1.11 & 1.09 & 1.12 & 1.10 & 0.99 & 0.97 & 1.22 & 1.21 & 1.17 & 1.18 & 1.06 & 1.07 & 1.07 & 1.07 & 1.08 & 1.12 & 1.16 & 1.14 & 1.05 & 1.04 \\
\hline PD & & 2.37 & 2.30 & 2.40 & 2.41 & 2.37 & 2.28 & 2.29 & 2.26 & 2.27 & 2.35 & 2.41 & 2.29 & 2.24 & 2.29 & 2.32 & 2.59 & 2.20 & 2.24 & 2.21 & 2.27 \\
\hline POR & & 53.09 & 52.61 & 53.24 & 54.22 & 58.17 & 57.39 & 46.57 & 46.45 & 48.47 & 49.86 & 56.02 & 53.06 & 52.44 & 53.27 & 53.41 & 56.86 & 47.47 & 49.35 & 52.59 & 54.18 \\
\hline $\mathrm{HC}$ & & 0.34 & 0.32 & 0.43 & 0.39 & 0.51 & 0.72 & 1.43 & 1.33 & 0.47 & 0.38 & 0.32 & 0.24 & 0.22 & 0.20 & 0.27 & 0.29 & 0.45 & 0.53 & 0.67 & 0.69 \\
\hline Texture & & clay & clay & clay & clay & clay & clay & clay & clay & clay & clay & clay & clay & clay & clay & clay & clay & clay & clay & clay & \\
\hline Sand & & 12 & 11 & 12 & 12 & 6 & 7 & 24 & 17 & 12 & 13 & 14 & 12 & 12 & 9 & 11 & 15 & 13 & 18 & 9 & \\
\hline Silt & & 25 & 20 & 25 & 25 & 28 & 26 & 26 & 24 & 28 & 18 & 19 & 16 & 16 & 16 & 25 & 20 & 19 & 17 & 22 & \\
\hline Clay & & 63 & 69 & 63 & 63 & 66 & 67 & 50 & 59 & 60 & 69 & 67 & 72 & 72 & 75 & 64 & 65 & 68 & 65 & 69 & \\
\hline $\mathrm{pH}$ & & 5.8 & 5.8 & 5.9 & 6.2 & 6.7 & 6.2 & 5.6 & 6.1 & 5.8 & 5.8 & 5.9 & 5.9 & 5.7 & 5.7 & 5.7 & 6.3 & 5.6 & 5.7 & 5.5 & 6. \\
\hline SOC & & 1.6 & 0.99 & 1.6 & 1.5 & 2.9 & 2.3 & 1.5 & 0.91 & 1.4 & 1.2 & 1.9 & 1.2 & 1.8 & 1.2 & 1.8 & 1.1 & 1.2 & 1.2 & 1.9 & 1.9 \\
\hline $\mathrm{T}-\mathrm{N}$ & & 0.15 & 0.10 & 0.15 & 0.11 & 0.21 & 0.12 & 0.08 & 0.06 & 0.09 & 0.10 & 0.14 & 0.09 & 0.12 & 0.09 & 0.11 & 0.12 & 0.05 & 0.09 & 0.25 & 0.13 \\
\hline$C / N$ & & 11 & 10 & 11 & 14 & 14 & 19 & 19 & 16 & 15 & 12 & 14 & 14 & 15 & 14 & 16 & 10 & 24 & 14 & 8 & 13 \\
\hline Av. P & & 41 & 24 & 31 & 34 & 13 & 16 & 17 & 21 & 40 & 22 & 37 & 25 & 14 & 13 & 26 & 24 & 30 & 37 & 32 & 20 \\
\hline Ex. K & & 0.22 & 0.50 & 0.35 & 0.58 & 0.31 & 0.41 & 0.17 & 0.44 & 0.04 & 0.26 & 0.50 & 0.55 & 0.51 & 0.69 & 0.50 & 0.59 & 0.39 & 0.52 & 0.26 & 0.14 \\
\hline Ex. $\mathrm{Na}$ & & 0.60 & 0.54 & 0.60 & 0.71 & 0.75 & 0.91 & 0.09 & 0.25 & 0.28 & 0.39 & 0.68 & 0.61 & 0.42 & 0.57 & 0.56 & 0.62 & 0.35 & 0.26 & 0.48 & 0.79 \\
\hline Ex. Ca & & 6.14 & 4.36 & 6.32 & 5.71 & 10.98 & 9.24 & 4.32 & 6.04 & 6.93 & 6.24 & 8.01 & 6.70 & 4.97 & 5.35 & 7.02 & 5.34 & 4.10 & 4.75 & 5.18 & 6.07 \\
\hline Ex. Mg & & 1.77 & 1.73 & 1.49 & 1.55 & 2.14 & 2.32 & 1.46 & 2.04 & 2.03 & 2.26 & 1.82 & 2.01 & 1.60 & 1.89 & 1.85 & 2.30 & 1.33 & 1.61 & 1.15 & 1.71 \\
\hline CEC & & 12.9 & 10.0 & 13.5 & 12.4 & 15.6 & 13.7 & 8.4 & 9.2 & 12.2 & 10.5 & 11.7 & 10.0 & 10.5 & 9.5 & 11.8 & 9.4 & 8.8 & 12.3 & 14.9 & 12.5 \\
\hline BS & & 68 & 72 & 65 & 69 & 91 & 94 & 72 & 96 & 76 & 87 & 94 & 99 & 71 & 89 & 84 & 94 & 70 & 58 & 47 & 70 \\
\hline
\end{tabular}

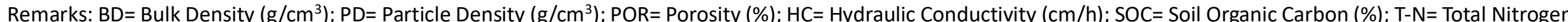

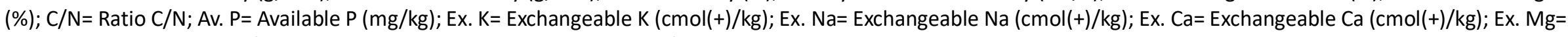
Exchangeable $\mathrm{Mg}(\mathrm{cmol}(+) / \mathrm{kg}) ; \mathrm{CEC}=$ Cation Exchange Capacity $(\mathrm{cmol}(+) / \mathrm{kg}) ; \mathrm{BS}=$ Base Saturation $(\%)$ 
The physical-chemical properties of the soil are used as a determinant indicator for quantitative soil quality (Table 2 ). A sampling at depths of $0-20 \mathrm{~cm}$ and $20-40 \mathrm{~cm}$ is assumed to represent the ability of the soil to support plant growth. Based on the analysis of the soil physical properties, the soil has a low bulk density $\left(<1.2 \mathrm{~g} \mathrm{~cm}^{-3}\right)$ and high porosity (40-60\%) with clay texture, indicating that the soil is easily cultivated to a depth of $40 \mathrm{~cm}$ with high ability to retain water and good rooting media. Mechanized tillage is constrained because of the depth and high plasticity of the soil. Soil permeability is slow to slow, indicating the low ability to pass water and poor drainage. The porosity and permeability parameters of the soil strengthen that the soil is easily flooded.

In general, the chemical properties of soil at a depth of $0-20 \mathrm{~cm}$ are relatively higher compared to at a depth of $20-40 \mathrm{~cm}$. Soil pH values are slightly acidic (5.5-6.5), base saturation is relatively high (more than $60 \%$ ), and cation exchange capacity is low (less than $\left.16 \mathrm{cmol}(+) \mathrm{kg}^{-1}\right)$. Pulungan \& Sartohadi (2018b) explained that the material from andesitic breccia parent material undergoing geothermal alteration showed high base saturation, low CEC, and high clay content. Organic $C$ content $<2 \%$ and total $\mathrm{N}<0.2 \%$ are categorized as low criteria. The use of organic fertilizer that is low and not continuous causes low organic $\mathrm{C}$ and total $\mathrm{N}$ content. The availability of $\mathrm{P}$ indicates low to moderate values that correlate with $\mathrm{pH}$ values. $\mathrm{pH}$ values tend to be slightly acidic, causing $\mathrm{P}$ to be fixed by $\mathrm{Al}$ and $\mathrm{Fe}$ in the soil. In general, the physical-chemical properties of quantitative soils can support plant growth.

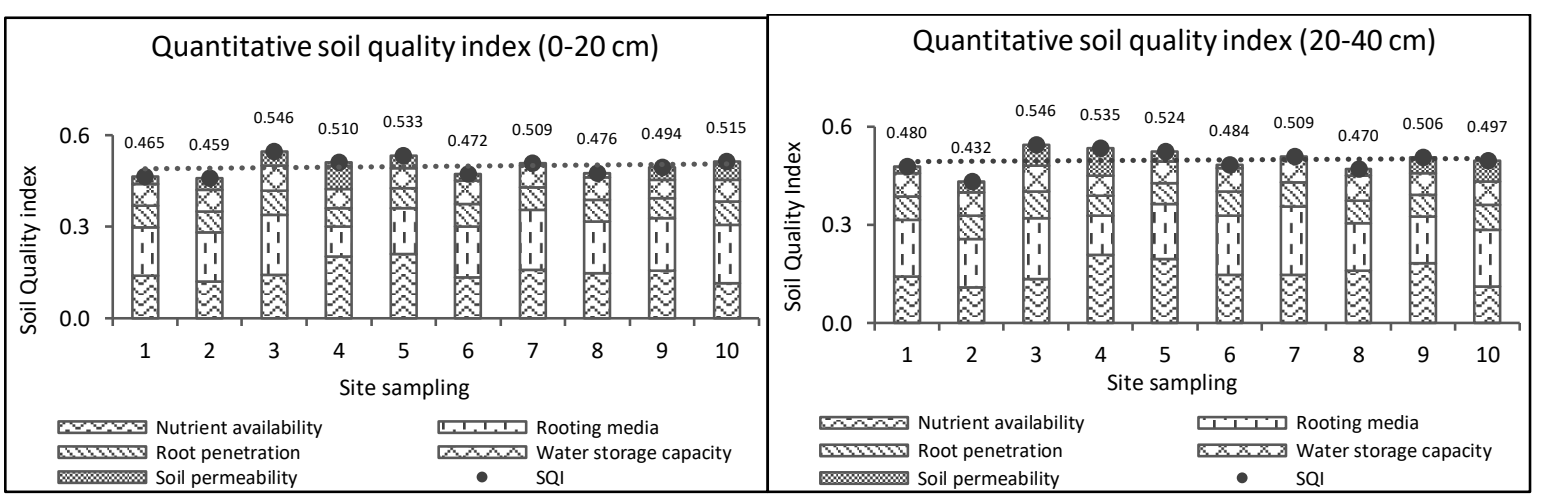

(a)

(b)

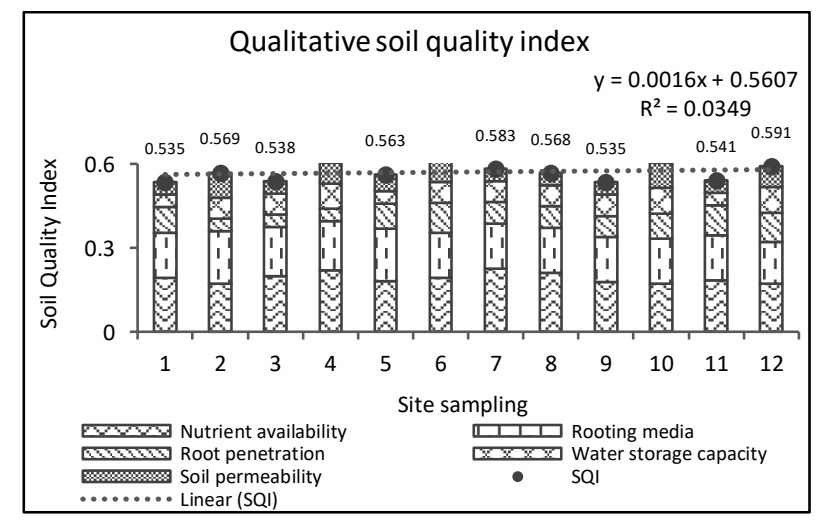

(c)

Figure 2. Quantitative soil quality index at $0-20 \mathrm{~cm}(\mathrm{a})$, at $20-40 \mathrm{~cm}(\mathrm{~b})$ and qualitative soil quality index(c) 


\section{DISCUSSION}

Knowledge of agricultural soil is very important to maintain or improve soil quality. Reliable, objective and consistent assessment of soil quality requires systematic methods to measure and interpret soil properties. Qualitative soil quality index was performed using the concept of ethnopedology. According to Barrera-Bassols \& Zinck (2003), ethnopedology aims to understand local approaches in the perception of indigenous land, local classification, assessment of soil quality, land use, and land management. Farmers' knowledge about soil/land and its management is a local and site-specific wisdom system.

The PC value was obtained by involving eigenvalue $>1$. At each selected PC, the loading factor with the highest value was determined. Other loading factors were determined based on correlation with a significance of 0.01 and Table 3. Principal Component Analysis (PCA)

\begin{tabular}{lrrr}
\hline Eigenvalue & 6.2728 & 3.3306 & 1.9155 \\
Proportion & 0.418 & 0.222 & 0.128 \\
Cumulative & 0.418 & 0.640 & 0.768 \\
\hline Variable & $\mathbf{P C 1}$ & $\mathbf{P C 2}$ & $\mathbf{P C 3}$ \\
\hline $\mathrm{pH}$ & 0.247 & -0.082 & 0.448 \\
Soil organic carbon & 0.311 & -0.213 & -0.084 \\
Total N & 0.290 & -0.128 & -0.325 \\
Available P & -0.086 & -0.128 & -0.367 \\
Exchangeable K & 0.040 & 0.417 & 0.144 \\
Exchangeable Na & $\mathbf{0 . 3 5 2}$ & 0.098 & 0.013 \\
Exchangeable Ca & 0.319 & -0.177 & 0.227 \\
Exchangeable Mg & 0.144 & 0.046 & $\mathbf{0 . 5 6 4}$ \\
Cation Exchange Capacity & 0.291 & -0.244 & -0.295 \\
Sand & $-\mathbf{0 . 3 3 1}$ & -0.110 & 0.107 \\
Silt & 0.092 & $-\mathbf{0 . 4 6 8}$ & 0.111 \\
Clay & 0.164 & $\mathbf{0 . 4 4 1}$ & -0.161 \\
Bulk density & $\mathbf{0 . 3 6 2}$ & -0.111 & 0.124 \\
Porosity & $\mathbf{0 . 3 6 6}$ & 0.104 & 0.015 \\
Hydraulic conductivity & 0.088 & $\mathbf{0 . 4 3 5}$ & -0.098 \\
\hline
\end{tabular}

Remark: Bold= minimum data set not less than $90 \%$ of the highest loading factor value. Table 3 shows the results of the PCA, which explained more than $76.8 \%$ of the variation of soil attributes. The minimum data set selected for quantitative soil quality analysis includes porosity, bulk density, $\mathrm{Na}$-dd, sand, silt, clay, permeability, and Mg-dd. Soil texture is the most basic physical properties of soil (Schoenholtz, Miegroet \& Burger, 2000) and is considered the most effective indicator of soil quality (Li et al., 2013). The selected soil texture becomes the minimum data set and correlates with bulk density, porosity, and permeability. Plant root systems, air, and water circulation can be negatively affected by increasing bulk density (Doran, 2002). Base cations such as $\mathrm{Na}-\mathrm{dd}$ and $\mathrm{Mg}$-dd become the minimum data set related to the response and availability of nutrients for plants. 
Table 4. Weighting on the soil function, qualitative soil quality, and quantitative soil quality

\begin{tabular}{|c|c|c|c|c|c|c|}
\hline \multirow{2}{*}{ Soil function } & \multicolumn{3}{|c|}{ Qualitative } & \multicolumn{3}{|c|}{ Quantitative } \\
\hline & $\mathbf{W}_{\mathrm{SF}}$ & Parameter & $\mathbf{W}_{\text {MDS }}$ & $\mathbf{W}_{\mathrm{SF}}$ & Parameter & $\mathbf{W}_{\text {MDS }}$ \\
\hline \multirow{2}{*}{ Nutrient availability } & \multirow{2}{*}{0.300} & Soil color & 0.600 & \multirow{2}{*}{0.302} & Ex. $\mathrm{Na}$ & 0.449 \\
\hline & & Plant condition & 0.400 & & Ex. Mg & 0.551 \\
\hline \multirow{3}{*}{ Rooting media } & \multirow{3}{*}{0.250} & \multirow{3}{*}{$\begin{array}{l}\text { Field texture } \\
\text { (coarse fraction) }\end{array}$} & \multirow{3}{*}{1.000} & \multirow{3}{*}{0.323} & Sand & 0.395 \\
\hline & & & & & Silt & 0.311 \\
\hline & & & & & Clay & 0.293 \\
\hline Root penetration & 0.150 & Ease of tillage & 1.000 & 0.140 & Bulk density & 1.000 \\
\hline Water storage capacity & 0.150 & Dry/wet period & 1.000 & 0.141 & Porosity & 1.000 \\
\hline Soil permeability & 0.150 & Drainage & 1.000 & 0.094 & $\begin{array}{l}\text { Hydraulic } \\
\text { conductivity }\end{array}$ & 1.000 \\
\hline
\end{tabular}

Remarks: $\mathrm{W}_{\mathrm{SF}}=$ Weighting factor of soil function; $\mathrm{W}_{\mathrm{MDS}}=$ Weighting factor of minimum data set

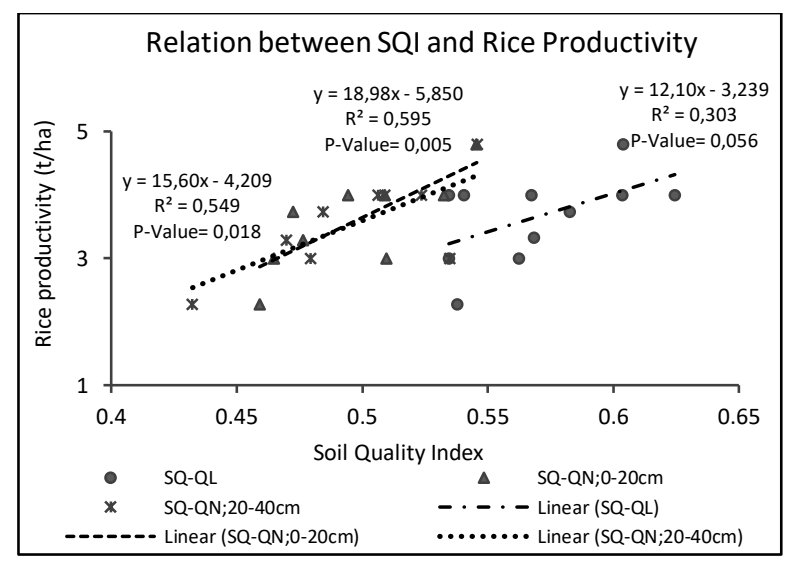

Figure 3. Relationship between soil quality index and rice productivity

Weighting was divided into two, namely weighting for each minimum data set and weighting on soil functions (Table 4). The linear scoring method requires little prior knowledge of the soil work system, while the non-linear scoring requires in-depth knowledge of the behavior and work of the soil indicator ( $\mathrm{Yu}$ et al., 2018). The non-linear scoring method is considered as an appropriate method for indexing soil quality indicators as has been done by previous researchers (Andrews et al., 2002; Askari \& Holden, 2015; Mukhopadhyay et al., 2016; Zhao et al., 2017; and Yu et al., 2018). The results of the study show that nonlinear scoring is considered more objective.

Figure 2 presents qualitative and quantitative soil quality indexes with the property of soil function indicator. The qualitative soil quality index presents the highest proportion of nutrient availability. Local understanding of farmers assumes that soil color and plant conditions interpret nutrient availability. The quantitative soil quality index presents rooting media as the highest proportion. Penetration and root development are influenced by soil texture as a function of rooting media. Both qualitative and quantitative soil functions positively affect plant responses. The effect of soil quality on the plant response can be seen in plant productivity. This research presents rice productivity data based on the results of farmer interviews and observations in the field when harvesting. The relationship between qualitative and quantitative soil quality on rice productivity is presented in Figure 3.

Quantitative soil quality had P-value $<0.05$ which is $0.005(0-20 \mathrm{~cm})$ and $0.018(20-$ $40 \mathrm{~cm}$ ), while qualitative soil quality has a Pvalue $>0.05$ (0.056). Quantitative soil quality 
shows a higher correlation ( $R^{2}$ value) than qualitative soil quality, indicating that quantitative soil quality is more objective and accurate. The quantitative soil quality shows a higher $R^{2}$ than qualitative soil quality. The quantitative and qualitative soil quality indexes show positive linear equations, which means that improvement in soil quality $(x)$ will be followed by plant response or rice productivity (y). The results of the study are in line with Masto et al. (2007), proving that the response of soil quality increased with long-term nutrition supply, which was followed by increased plant growth. The best linear relationship is shown in quantitative soil quality at $0-20 \mathrm{~cm}$ depth $\left(R^{2}=0.595\right)$ and continued at $20-40 \mathrm{~cm}$ depth $\left(R^{2}=0.549\right)$. The linearity results are in accordance with the predictions and expectations of researchers, which prove that the indexing of soil quality multiplied by soil functions is more objective and accurate.

\section{CONCLUSION}

Soil quality assessment using the soil function approach is more objective and accurate. The soil function information obtained has weighting criteria based on the farmers' perspective and the proportion of each PC. Soil function information includes nutrient availability, rooting media, root penetration, water storage capacity, and water permeability. Positive linearity is shown between the index of soil quality and the productivity of lowland rice. Quantitative soil quality can be recommended to researchers, stakeholders, and farmers. However, the qualitative soil quality method was useful, especially for farmers with limited time and cost.

\section{ACKNOWLEDGMENTS}

The authors would like to thank the Agricultural Research and Development Agency for funding the field research and laboratory analysis of this research. The authors also express gratitude to Universitas Gadjah Mada for funding the publication of this scientific article through the 2019 Final Assignment Recognition program.

\section{REFERENCES}

Adeyolanu, O. D., \& Ogunkunle, A. O. (2016). Comparison of qualitative and quantitative approaches to soil quality assessment for agricultural purposes in South-western Nigeria. Cogent Food \& Agriculture, 2(1), 1-10. https://doi.org/10.1080/23311932.2016. 1149914

Andrews, S. S., Karlen, D. L., \& Cambardella, C. A. (2004). The Soil Management Assessment Framework. Soil Science Society of America Journal, 68(6), 1945. https://doi.org/10.2136/sssaj2004.1945

Andrews, S. S., Karlen, D. L., \& Mitchell, J. P. (2002). A comparison of soil quality indexing methods for vegetable production systems in Northern California. Agriculture, Ecosystems and Environment, 90(1), 25-45. https://doi.org/10.1016/S01678809(01)00174-8

Arifin, Z. (2011). Analisis Nilai Indeks Kualitas Tanah Entisol Pada Penggunaan Lahan Yang Berbeda Analysis of Soil Quality Index of Entisol With Different Land Use. Agroteksos, 21(1), 47-54.

Askari, M. S., \& Holden, N. M. (2015). Quantitative soil quality indexing of temperate arable management systems. Soil and Tillage Research, 150, 57-67. https://doi.org/10.1016/j.still.2015.01.01 0

Barrera-Bassols, N., \& Zinck, J. A. (2003). Ethnopedology: A worldwide view on the soil knowledge of local people. Geoderma, 111(3-4), 171-195. https://doi.org/10.1016/S00167061(02)00263-X

Biswas, S., Hazra, G. C., Purakayastha, T. J., Saha, N., Mitran, T., Singha Roy, S., ... Mandal, B. (2017). Establishment of critical limits of indicators and indices of 
soil quality in rice-rice cropping systems under different soil orders. Geoderma, 292, 34-48. https://doi.org/10.1016/j.geoderma.201 7.01 .003

Budianto, Y. (2016). Keterdapatan Sensitive Clay pada Lokasi Longsorlahan di DAS Bompon, Kabupaten Magelang, Jawa Tengah. Sekripsi. Universitas Gadjah Mada Yogyakarta.

Bünemann, E. K., Bongiorno, G., Bai, Z., Creamer, R. E., De Deyn, G., de Goede, R., ... Brussaard, L. (2018). Soil quality - A critical review. Soil Biology and Biochemistry, 120(September 2017), 105-125.

https://doi.org/10.1016/j.soilbio.2018.01 .030

Carter, M. ., \& Gregorich, E. . (2009). Soil Sampling and Methods of Analysis. In Journal of Environment Quality (Vol. 38). https://doi.org/10.2134/jeq2008.0018br

Doran, J. W. (2002). Soil health and global sustainability: Translating science into practice. Agriculture, Ecosystems and Environment, 88(2), 119-127. https://doi.org/10.1016/S01678809(01)00246-8

Fierer, N., Bradford, M. A., \& Jackson, R. B. (2007). Toward an ecological classification of soil bacteria. Ecology, 88(6), 1354-1364. https://doi.org/10.1890/05-1839

Govaerts, B., Sayre, K. D., \& Deckers, J. (2006). A minimum data set for soil quality assessment of wheat and maize cropping in the highlands of Mexico. Soil and Tillage Research, 87(2), 163-174. https://doi.org/10.1016/j.still.2005.03.00 5

Hollweck, T. (2016). Robert K. Yin. (2014). Case Study Research Design and Methods (5th ed.). Thousand Oaks, CA: Sage. 282 pages. The Canadian Journal of Program Evaluation, 1(2014), 108-110. https://doi.org/10.3138/cjpe.30.1.108

Jobbagy, E. G., \& Jackson, R. B. (2004). THE UPLIFT OF SOIL NUTRIENTS BY PLANTS: BIOGEOCHEMICAL Special Feature. Ecology, 85(9), 2380-2389.

Karlen, D. L., Andrews, S. S., Weinhold, B. J., \&
Doran, J. W. (2003). Soil quality: Humankind's foundation for survival a research editorial by conservation professionals. Journal of Soil and Water Conservation, 58(4), 171-179. Retrieved from

http://www.jswconline.org/content/58/ 4/171.abstract

Li, P., Zhang, T., Wang, X., \& Yu, D. (2013). Development of biological soil quality indicator system for subtropical China. Soil and Tillage Research, 126, 112-118. https://doi.org/10.1016/j.still.2012.07.01 1

Lima, A. C. R., Brussaard, L., Totola, M. R., Hoogmoed, W. B., \& de Goede, R. G. M. (2013). A functional evaluation of three indicator sets for assessing soil quality. Applied Soil Ecology, 64, 194-200. https://doi.org/10.1016/j.apsoil.2012.12. 009

Masto, R. E., Chhonkar, P. K., Singh, D., \& Patra, A. K. (2007). Soil quality response to longterm nutrient and crop management on a semi-arid Inceptisol. Agriculture, Ecosystems and Environment, 118(1-4), 130-142. https://doi.org/10.1016/j.agee.2006.05. 008

Masto, R. E., Sheik, S., Nehru, G., Selvi, V. A., George, J., \& Ram, L. C. (2015). Assessment of environmental soil quality around Sonepur Bazari mine of Raniganj coalfield, India. Solid Earth, 6(3), 811821. https://doi.org/10.5194/se-6-8112015

Mukhopadhyay, S., Masto, R. E., Yadav, A., George, J., Ram, L. C., \& Shukla, S. P. (2016). Soil quality index for evaluation of reclaimed coal mine spoil. Science of the Total Environment, 542, 540-550. https://doi.org/10.1016/j.scitotenv.2015 .10 .035

Murage, E. W., Karanja, N. K., Smithson, P. C., \& Woomer, P. L. (2000). Diagnostic indicators of soil quality in productive and non-productive smallholders' fields of Kenya's Central Highlands. Agriculture, Ecosystems and Environment, 79(1), 1-8. https://doi.org/10.1016/S01678809(99)00142-5 
Noviyanto, A., Purwanto, P., Minardi, S., \& Supriyadi, S. (2017). The assessment of soil quality of various age of land reclamation after coal mining: a chronosequence study. Journal of Degraded and Mining Lands Management, 5(1), 1009-1018. https://doi.org/10.15243/jdmlm.2017.05 1.1009

Obade, V. de P. (2019). Integrating management information with soil quality dynamics to monitor agricultural productivity. Science of the Total Environment, 651, 2036-2043. https://doi.org/10.1016/j.scitotenv.2018 .10 .106

Obade, V. de P., \& Lal, R. (2016). Towards a standard technique for soil quality assessment. Geoderma, 265, 96-102. https://doi.org/10.1016/j.geoderma.201 5.11 .023

Pulungan, N. A., \& Sartohadi, J. (2018a). New Approach to Soil Formation in the Transitional Landscape Zone: Weathering and Alteration of Parent Rocks. Journal of Environments, 5(1), 1-7. https://doi.org/10.20448/journal.505.20 18.51.1.7

Pulungan, N. A., \& Sartohadi, J. (2018b). Variability of Soil Development in Hilly Region, Bogowonto Catchment, Java, Indonesia. International Journal of Soil
Science, $\quad 13(1), \quad 1-8$. https://doi.org/10.3923/ijss.2018.1.8

Rashidi, M., Seilsepour, M., Ranjbar, I., Gholami, M., \& Abbassi, S. (2010). Evaluation of Some Soil Quality Indicators in the Varamin Region, Iran. Natural Resources Research, 9(1), 101-108.

Rezaei, S. A., Gilkes, R. J., \& Andrews, S. S. (2006). A minimum data set for assessing soil quality in rangelands. 136, 229-234. https://doi.org/10.1016/j.geoderma.200 6.03.021

Schoenholtz, S. ., Miegroet, H. ., \& Burger, J. . (2000). Imprinting in guinea-pigs [32]. Nature, 220(5172), 1148. https://doi.org/10.1038/2201148a0

Yu, P., Liu, S., Zhang, L., Li, Q., \& Zhou, D. (2018). Selecting the minimum data set and quantitative soil quality indexing of alkaline soils under different land uses in northeastern China. Science of the Total Environment, 616-617, 564-571. https://doi.org/10.1016/j.scitotenv.2017 .10 .301

Zhao, D., Xu, M., Liu, G., Ma, L., Zhang, S., Xiao, T., \& Peng, G. (2017). Effect of vegetation type on microstructure of soil aggregates on the Loess Plateau, China. Agriculture, Ecosystems and Environment, 242, 1-8. https://doi.org/10.1016/j.agee.2017.03. 014 